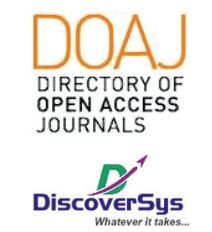

Published by DiscoverSys

\section{Karakteristik gambaran sitologi pap-smear sebagai tes skrining untuk lesi pra-kanker serviks di RSUP Sanglah, Denpasar, Bali}

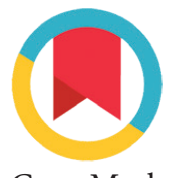

CrossMark

\author{
Putu Risky Yoga Pradnyana, ${ }^{1 *}$ Anak Agung Ayu Ngurah Susraini, ${ }^{2}$ \\ I Gusti Ayu Sri Mahendra Dewi ${ }^{2}$
}

\title{
ABSTRACT
}

Background: Cervical cancer is the second most often cancer that occurs in women worldwide after breast cancer and as many as $84 \%$ of the cases occur in developing countries. Pap Smear is a screening method that widely used for cervical cancer screening. The aim of the study is to obtain the characteristic data of pap smear cytology as a pre-cervical cancer screening in Sanglah General Hospital 2016 - 2017 period.

Methods: This study was descriptive research with cross sectional study design. The sampling technique is total sampling where the research data comes from the cytology registration book results of the Anatomical Pathology Laboratory at Sanglah General Hospital Denpasar 1 January 2016 - 31 December 2017 period which has fulfilled the inclusion criteria and does not meet the exclusion criteria. Data were analyzed using SPSS version 20 for Windows.

Results: This study collected as many as 590 samples. Most of the pap smear patients at Sanglah General Hospital Denpasar were 41-50 year old group as many as 188 people (31.86\%), most of the patients parities were nullipara parities as many as 324 people (54.92\%), most had no complaints as many as 261 people (44.24\%) and most of the pap smear cytology description was Reactive Cellular Changes Associated with Inflammation (RCCl) as many as 261 people (44.64\%). Conclusion: Most of the respondents who underwent pap-smear test as a screening step for pre-cancerous lesions had a cytological picture of Reactive cellular changes associated with Inflammation (RCCI)

Keywords: Precancer, Pap Smear, cervix, parity, cytology, screening Cite This Article: Pradnyana, P.R.Y., Susraini, A.A.A.N., Dewi, I.G.A.S.M. 2019. Karakteristik gambaran sitologi pap-smear sebagai tes skrining untuk lesi pra-kanker serviks di RSUP Sanglah, Denpasar, Bali. Intisari Sains Medis 10(3): 557-562. D0I: 10.15562/ism.v10i3.461

\section{ABSTRAK}

Latar Belakang: Kanker serviks merupakan kanker nomor 2 yang paling sering terjadi pada wanita di seluruh dunia setelah kanker payudara dan sebanyak $84 \%$ kasus kanker serviks terjadi di negara negara berkembang. Pap Smear merupakan metode skrining yang banyak digunakan untuk skrining kanker serviks. Tujuan dari penelitian ini adalah untuk mengetahui data karakteristik gambaran sitologi pap smear sebagai skrining pre kanker serviks di RSUP Sanglah tahun 2016 - 2017.

Metode: Penelitian ini merupakan penelitian deskriptif dengan rancangan penelitian cross-sectional. Teknik pengambilan sampel berupa total sampling dimana data penelitian berasal dari buku registrasi sitologi hasil pemeriksaan Laboratorium Patologi Anatomi di
RSUP Sanglah Denpasar periode 1 Januari 2016 - 31 Desember 2017 yang telah memenuhi kriteria inklusi dan tidak memenuhi kriteria eksklusi. Data dianalisis menggunakan SPSS versi 20 untuk Windows. Hasil: Terkumpul sebanyak 590 sampel terbanyak terjadi pada kelompok 41-50 tahun sebanyak 188 orang $(31,86 \%)$, memiliki jumlah paritas nullipara sebanyak 324 orang $(54,92 \%)$, sebagian besar tidak memiliki keluhan sebanyak 261 orang (44,24\%), dan dengan gambaran sitologi pap smear Reactive cellular changes associated with Inflammation (RCCI) sebanyak 261 orang (44,64\%).

Kesimpulan: Sebagian besar responden yang menjalani pap-smear sebagai langkah skrining untuk lesi pra kanker memiliki gambaran sitologi Reactive cellular changes associated with Inflammation (RCCI) 2SMF Patologi Anatomi, Kedokteran, Universitas Udayana, RSUP Sanglah Denpasar, Bali, Indonesia

\section{*Korespondensi: \\ Putu Risky Yoga Pradnyana, Program Studi Sarjana Kedokteran dan Profesi Dokter, Fakultas Kedokteran Universitas Udayana, Bali, Indonesia; riskyyoga69@gmail.com}

Diterima: 27-03-2019

Disetujui: 16-08-2019

Diterbitkan: 01-12-2019

Kata Kunci: Prekanker, Pap Smear, serviks, paritas, sitologi, skrining Cite Pasal Ini: Pradnyana, P.R.Y., Susraini, A.A.A.N., Dewi, I.G.A.S.M. 2019. Karakteristik gambaran sitologi pap-smear sebagai tes skrining untuk lesi pra-kanker serviks di RSUP Sanglah, Denpasar, Bali. Intisari Sains Medis 10(3): 557-562. D0I: 10.15562/ism.v10i3.461

\section{PENDAHULUAN}

Serviks merupakan bagian bawah dari uterus. Serviks ini berbentuk silindris. Serviks ini berada di ujung dari vagina, dan merupakan pemisah antara uterus dan vagina. Serviks dapat mengalami suatu keganasan terutama terjadi pada bagian mukosa serviks. Kanker ini pun dapat berkembang secara lokal pada serviks ataupun dapat menyebar ke bagian uterus ataupun organ-organ pada pelvis lainnya. 
Kanker serviks merupakan kanker genital yang sangat sering terjadi pada wanita. Kanker serviks ini merupakan kanker yang disebabkan oleh infeksi virus Human papilloma virus (HPV) khususnya serotipe 16 dan $18 .{ }^{1}$ Human papilloma virus tipe 16 ini merupakan virus yang pertama kali diisolasi pada tahun 1983 dan telah dideklarasi sebagai karsinogen pada manusia. ${ }^{2}$ Risiko untuk terkena kanker serviks menjadi lebih tingi pada orangorang yang melakukan hubungan seks dengan banyak pasangan ataupun berhubungan seks dengan orang yang telah mengidap neoplasia pada organ genitalnya. Karsinoma serviks ini memiliki banyak tipe berdasarkan histopatologinya, yaitu squamous cell carcinoma (keratinizing/non-keratinizing), endometrioid adenocarcinoma, clear cell adenocarcinoma, adenosquamous carcinoma, adenoid cystic carcinoma, small cell carcinoma, dan undifferentiated carcinoma. ${ }^{3}$

Di dunia, kanker serviks merupakan kanker nomor 2 yang paling sering terjadi pada wanita setelah kanker payudara. ${ }^{4}$ Di Amerika Serikat, kanker serviks ini merupakan kanker nomor 4 yang terjadi pada wanita dan merupakan nomor 6 sebagai kanker wanita yang menyebabkan kematian. Menurut World Cancer Research Fund, pada tahun 2012 sebanyak 84\% kasus kanker serviks terjadi di negara - negara berkembang. Hal tersebut menunjukkan bahwa sebagian besar kasus kanker serviks tersebut berada di negara berkembang. Di Indonesia, sebagai salah satu negara berkembang, setiap tahunnya diperkirakan terdapat 40.000 jumlah kasus baru pada kanker serviks ini. Di Rumah Sakit Cipto Mangunkusumo sendiri, pada tahun 2005, frekuensi kanker serviks mencapai sebesar $76.2 \%$ diantara kanker pada organ genital wanita lainnya. Pasien rata-rata datang dengan keadaan stadium lanjut yaitu pada stadium IIB-IVB yaitu sebanyak $66.4 \% .^{5}$

Tingginya angka kanker serviks dan tingginya angka kematian yang disebabkan kanker serviks membuat kita memerlukan tindakan yang preventif terhadap kanker serviks tersebut. Dengan perilaku seksual yang sehat dan skrining yang baik diharapkan dapat menurunkan angka dari kanker serviks. Penelitian sebelumnya menunjukkan bahwa parameter laboratorium seperti penggunaan rasio neutrofil dan limfosit (NLR) dapat dipergunakan sebagai nilai prediktif dalam menentukan keganasan kanker serviks dengan sensitivitas tinggi. ${ }^{6}$ Akan tetapi upaya skrining menggunakan pemeriksaan histopatologi seperti pap smear lebih sering dipergunakan masyarakat berkembang. Dengan dilakukan skrining pun, masyarakat dapat menjadi tahu bagaimana keadaannya sehingga jika hasilnya positif, masyarakat dapat melakukan terapi yang lebih dini agar prognosis dari kanker serviks tersebut menjadi lebih baik.

Pap Smear merupakan metode skrining yang banyak digunakan untuk skrining kanker serviks. Pap smear dilakukan dengan mengambil sampel sitologi dari serviks untuk mendiagnosis kanker serviks. Pemeriksaan pap smear dikatakan memiliki akurasi dalam mendiagnosis hingga 98\% dan memiliki tingkat spesifisitas mencapai 93\%. Akan tetapi, pap smear masih mungkin memberikan hasil negatif palsu. Dimana studi terdahulu menunjukkan bahwa tes ini dapat memberikan kemungkinan false negatif sebesar 5\%-15\%., Dalam berbagai penelitian akurasi dari pap smear dalam mendiagnosis kanker serviks bervariasi, yaitu sensitifitas hingga $98 \%$, nilai prediksi positif $+80,2 \%$, nilai prediksi negatif $+91,3 \%$ dan angka positif palsu berkisar antara 3\%-15\%. Di Indonesia sendiri, dari beberapa penelitian didapatkan bahwa sensitifitas pap smear mencapai $96,2 \%$, nilai prediksi positif sebesar $62,5 \%$ dan nilai prediksi negatif sebesar $91,5 \%$.

Skrining pada kanker serviks ini sangatlah penting. Hal tersebut sangat mempengaruhi prognosis dari kanker serviks. Dengan diagnosis yang lebih akurat dan mengetahui hasil dari skrining tersebut diharapkan dapat menurunkan angka kematian akibat kanker serviks dan dapat menjadi suatu tindakan yang lebih dini untuk pemilihan terapi yang tepat jika terdiagnosis kanker serviks. Selain itu, angka kejadian kanker serviks baik di luar negeri mapun di Indonesia selalu meningkat dari tahun ke tahun. Belum banyak data penelitian mengenai karakteristik gambaran sitologi Pap Smear sebagai tes skrining untuk lesi prekanker serviks yang dilaporkan di Indonesia khususnya di Bali. Berdasarkan pemaparan yang telah diuraikan di atas, maka penulis betujuan untuk mengetahui mengenai karakteristik gambaran sitologi pap smear sebagai tes skrining untuk lesi prekanker serviks di RSUP Sanglah, Bali

\section{METODE}

Penelitian deskriptif observasional dengan rancangan penelitian potong lintang dilaksanakan pada Laboratorium Patologi Anatomi RSUP Sanglah Denpasar, pada bulan September 2018 sampai dengan November 2018. Subyek penelitian dipilih dari populasi yang memenuhi kriteria inklusi yaitu pasien yang melakukan tes skrining pap smear yang terdata lengkap di catatan registrasi sitologi hasil pemeriksaan Laboratorium Patologi Anatomi di RSUP Sanglah tahun 2016 - 2017. Serta tidak memenuhi kriteria eksklusi yaitu data pasien yang sudah pernah terdiagnosis suatu karsinoma, 
sudah pernah mendapat terapi karsinoma seperti kemoradiasi, serta pasien dengan hasil pap smear yang tidak adekuat untuk di evaluasi.

Teknik penentuan sampel yaitu total sampling. Jumlah sampel yang diambil adalah seluruh populasi yang ada hingga batas waktu yang ditentukan. Dimana pada penelitian ini peneliti mengambil populasi yang melakukan skrining pap smear pada tahun 2016 - 2017. Data berupa data sekunder yang didapatkan dari data rekam medis pasien yang tercatat dalam buku registrasi hasil pemeriksaan Laboratorium Patologi Anatomi RSUP Sanglah tahun 2016 - 2017. Adapun beberapa kriteria karakteristik pemeriksaan sitologi pap smear yang dilakukan pada studi ini adalah: usia, paritas, keluhan, dan gambaran hasil sitologi yang terbagi dalam data kategorikal dan ditampilkan dalam bentuk persentase. Data yang diperoleh

Tabel 1 Karakteristik demografis pasien yang melakukan skrining pap smear berdasarkan usia, paritas, dan keluhan

\begin{tabular}{|c|c|c|}
\hline Parameter & Frekuensi $(n=590)$ & Persentase (\%) \\
\hline \multicolumn{3}{|l|}{ Usia } \\
\hline$\leq 20$ tahun & 7 & 1,19 \\
\hline $21-30$ tahun & 63 & 10,68 \\
\hline $31-40$ tahun & 111 & 18,81 \\
\hline $41-50$ tahun & 188 & 31,86 \\
\hline $51-60$ tahun & 122 & 20,68 \\
\hline $61-70$ tahun & 76 & 12,88 \\
\hline$>70$ tahun & 23 & 3,90 \\
\hline \multicolumn{3}{|l|}{ Paritas } \\
\hline Nullipara & 324 & 54,92 \\
\hline$<3$ & 201 & 34,07 \\
\hline$\geq 3$ & 65 & 11,02 \\
\hline \multicolumn{3}{|l|}{ Keluhan } \\
\hline Tak ada keluhan & 261 & 44,24 \\
\hline Keluarnya discharge & 240 & 40,68 \\
\hline Perdarahan & 21 & 3,56 \\
\hline Gatal & 2 & 0,34 \\
\hline Nyeri perut bagian bawah & 5 & 0,85 \\
\hline Kehamilan + discharge & 1 & 0,17 \\
\hline Discharge + perdarahan & 20 & 3,39 \\
\hline discharge + gatal & 13 & 2,20 \\
\hline Discharge + berbau & 12 & 2,03 \\
\hline $\begin{array}{l}\text { Discharge + nyeri buang air } \\
\text { kecil }\end{array}$ & 1 & 0,17 \\
\hline $\begin{array}{l}\text { Discharge + berbau }+ \\
\text { perdarahan }\end{array}$ & 5 & 0,85 \\
\hline Discharge + berbau + gatal & 9 & 1,53 \\
\hline
\end{tabular}

kemudian dianalisis dengan bantuan software IBM SPSS Statistics 20 untuk di bahas secara deskriptif.

\section{HASIL}

Hasil penelitian menunjukkan bahwa sampel dengan rentang usia $\leq 20$ tahun merupakan kelompok usia terendah dengan jumlah sampel sebanyak tujuh orang (1.19\%). Pada rentang usia 21-30 tahun tercatat sebanyak 63 orang (10.68\%). Selanjutnya sebanyak 111 orang (18.81\%) merupakan sampel dengan rentang usia 31-40 tahun. Kelompok dengan rentang usia 41-50 tahun merupakan kelompok yang terbanyak yakni sebanyak 188 orang (31.86\%). Sebanyak 122 orang (20.68\%) tercatat pada kelompok dengan rentang usia 51-60 tahun, sebanyak 76 orang $(12.88 \%)$ tercatat pada rentang usia 61-70 tahun, dan pada rentang usia $>70$ tahun tercatat sebanyak 23 orang (3.90\%). Hasil penelitian Distribusi Pasien yang Melakukan Skrining Pap Smear di RSUP Sanglah Denpasar Tahun 2016 - 2017 berdasarkan Karakteristik Usia dapat dilihat pada Tabel 1.

Hasil penelitian menunjukan bahwa sampel terbanyak memiliki jumlah paritas nullipara yaitu sebanyak 324 orang (54.92\%). Sebanyak 201 orang (34.07\%) memiliki jumlah paritas kurang dari tiga, dan sebanyak 65 orang (11.02\%) pada memiliki jumlah paritas $\geq 3$. Adapun data dari variabel paritas pada penelitian ini dapat dilihat pada Tabel 1.

Mayoritas sampel penelitian tidak memiliki keluhan, yaitu sebanyak 261 orang (44.24\%). Sebanyak 240 orang (40.68\%) lainnya mengeluh keluarnya discharge, 21 orang $(3.56 \%)$ mengeluh mengalami perdarahan, 20 orang (3.39\%) mengeluh keluarnya discharge disertai perdarahan, 13 orang $(2.20 \%)$ mengeluhkan keluarnya discharge disertai gatal, 12 orang (2.03\%) mengeluh keluar discharge berbau, sembilan orang (1.53\%) mengeluh keluarnya discharge berbau disertai gatal, masing masing lima orang $(0.85 \%)$ mengeluh keluarnya discharge berbau disertai perdarahan dan nyeri perut, dua orang $(0.34 \%)$ hanya mengeluh gatal, serta masing masing satu orang $(0.17 \%)$ mengeluh keluarnya discharge dengan nyeri buang air kecil serta kehamilan disertai keluarnya discharge (Tabel 1).

Hasil pap smear berupa Reactive cellular changes associated with Inflammation ditemukan terbanyak yaitu sebanyak 261 orang $(44,24 \%)$, tidak terlalu berbeda pada kelompok Normal Cellular Findings yaitu sebanyak 125 orang $(21,18 \%)$. Sebanyak 99 orang (16,78\%) ditemukan adanya Athrophy, 34 orang $(5,76 \%)$ dinyatakan dengan hasil Shift in flora suggestive of bacterial vaginosis, 22 orang (3,73\%) dinyatakan dengan Atypical squamous cells of undetermined significance (ASC-US), 19 orang 
Tabel 2 Distribusi pasien yang melakukan skrining pap smear di RSUP Sanglah Denpasar berdasarkan karakteristik hasil sitologi Bethesda 2014

\begin{tabular}{lcc}
\hline Hasil Sitologi Bethesda 2014 & Frekuensi (n=590) & Persentase \\
\hline Negative for intraepithelial lesion or malignancy & 545 & 92.37 \\
Non Neoplastic Findings & 360 & 61,01 \\
Atrophy & 99 & 16,78 \\
Reactive cellular changes associated with inflammation & 261 & 44,24 \\
Organism & 60 & 10,17 \\
$\quad$ Trichomonas Vaginalis & 7 & 1,19 \\
$\quad$ Fungal organisms (Candida sp.) & 19 & 3,22 \\
$\quad$ Shift in flora suggestive of bacterial vaginosis & 34 & 5,76 \\
Normal Cellular Findings & 125 & 21,18 \\
Epithelial Cell Abnormalities & 45 & 7,63 \\
Squamous Cell & 45 & 7,63 \\
Atypical squamous cell & 40 & 6,78 \\
Atypical squamous cells of undetermined significance (ASC-US) & 22 & 3,73 \\
Atypical squamous cells cannot exclude HSIL (ASC-H) & 18 & 3,05 \\
Low-grade squamous intraepithelial lesion (LSIL) & 3 & 0,51 \\
High-grade squamous intraepithelial lesion (HSIL) & 2 & 0,34 \\
\hline
\end{tabular}

(3,22\%) dinyatakan dengan hasil Fungal organisms (Candida sp.), lalu 18 orang (3.05\%) dinyatakan dengan hasil Atypical squamous cells cannot exclude HSIL (ASC-H), tujuh orang (1.19\%) ditemukan organisme Trichomonas vaginalis, dan tiga orang (0.51\%) dinyatakan dengan hasil Low-grade squamous intraepithelial lesion (LSIL), dan yang terendah ditemukan adalah hasil High-grade squamous intraepithelial lesion (HSIL) yaitu sebanyak dua orang $(0.34 \%)$ (Tabel 2).

\section{PEMBAHASAN}

Hasil penelitian menunjukan karakteristik pasien yang melakukan skrining pap smear di RSUP Sanglah tahun 2016 - 2017 yang memiliki angka tertinggi yaitu pada rentang usia 41 - 50 tahun yaitu sebanyak 188 orang $(31,86 \%)$ dan yang terendah sebanyak tujuh orang $(1,19 \%)$ pada kelompok usia $\leq 20$ tahun. Hasil tersebut menunjukkan bahwa terdapat kesesuaian dengan penelitian yang sebelumnya pernah dilakukan. Rentang usia 41-50 tahun tertinggi juga ditemukan pada penelitian di Puskesmas Tanah Kali Kedinding dan Rumah Sakit Mawadah Mojokerto tahun 2015. ${ }^{7}$ Selain itu menurut literatur dikatakan kanker serviks lebih sering terdapat pada usia diatas 30 hingga 55 tahun, hal tersebut juga dapat menjadi alasan banyaknya wanita dengan usia $41-50$ tahun melakukan tes skrining pap smear.
Penelitian ini juga menunjukkan bahwa jumlah paritas tertinggi pada penelitian ini pada kelompok nullipara yaitu sebanyak 324 orang (54,92\%), sedangkan angka terendah terdapat pada kelompok paritas $\geq 3$ yaitu sebanyak 65 orang $(11,02 \%)$. Hasil tersebut menunjukkan bahwa lebih dari separuh dari total sampel keseluruhan belum pernah melakukan proses kelahiran. Hasil tersebut memiliki sedikit perbedaan pada beberapa penelitian sebelumnya. Menurut hasil penelitian dari Wiwit Ade et al di Kecamatan Tenayan Raya Pekanbaru, jumlah paritas yang ditemukan pada penelitian tersebut paling banyak pada kelompok paritas kurang dari tiga namun tidak nullipara. ${ }^{8}$ Begitu pula dengan penelitian oleh Fetty Try et al yang dilaksanakan di Kecamatan Marpoyan Damai Pekanbaru juga mendapatkan hasil bahwa angka tertinggi yang ditemukan pada kelompok jumlah paritas kurang dari tiga namun tidak nullipara. ${ }^{9}$ Hal tersebut terjadi karena peneliti mengambil sampel dari pasien RSUP Sanglah di Denpasar sedangkan pada penelitian sebelumnya mengambil sampel pada wanita pekerja seksual tidak langsung di Pekanbaru. Hal tersebut bisa saja terjadi karena perbedaan latar belakang pekerjaan diantara populasi yang peneliti ambil, selain itu perbedaan kebiasaan penggunaan kontrasepsi, tingkat pendidikan, serta keikutsertaan pada program Keluarga Berencana dapat menjadi alasan dari perbedaan hasil yang didapatkan tersebut. 
Karakteristik pasien yang melakukan skrining pap smear di RSUP Sanglah Denpasar tahun 2016 - 2017 berdasarkan karakteristik keluhan terbanyak adalah tidak memiliki keluhan yaitu 261 orang $(46,84 \%)$. Hasil ini dapat memperlihatkan perbedaan dengan beberapa penelitian yang telah dilakukan sebelumnya oleh A. Verma et al tahun 2017 yang dilakukan di Himachal Pradesh, India menunjukkan bahwa keluarnya discharge merupakan keluhan terbanyak dari orang orang yang melakukan skrining pap smear yaitu sebesar $57,5 \%{ }^{10}$ Pada penelitian lainnya yang dilakukan oleh Mahadik et al tahun 2016 di Gujarat, India, menunjukkan juga bahwa keluarnya discharge merupakan keluhan terbanyak dengan persentase $21,64 \%$ dari total sampel orang yang melakukan skrining pap smear yang diteliti. ${ }^{11}$ Hal tersebut bisa terjadi karena adanya perbedaan karakteristik populasi tempat sampel diambil dimana sampel yang peneliti ambil berada di Indonesia, sedangkan sampel pada penelitian sebelumnya berada di India. Perbedaan kemajuan ekonomi kedua negara dan tingkat pengetahuan kedua negara juga dapat menjadi alasan perdebadaan hasil pada populasi yang peneliti lakukan.

Kemudian yang terakhir, hasil skrining sitologi pap smear terbanyak yang ditemukan di RSUP Sanglah pada tahun 2016 - 2017 pada kelompok Reactive cellular changes associated with Inflammation yaitu sebanyak 261 orang $(44,64 \%)$, dan kelompok High-grade squamous intraepithelial lesion (HSIL) merupakan yang terendah yaitu dua orang $(0,34 \%)$. Hasil tersebut sesuai dengan penelitian yang dilakukan oleh Mehmetoglu et al., yang dilakukan di Turkey pada tahun 2010, dimana pada penelitian tersebut juga ditemukan jumlah yang dinyatakan dengan hasil Reactive cellular changes due to Inflammation merupakan yang tertinggi dengan persentase $67,2 \%$ dan High-grade squamous intraepithelial lesion (HSIL) merupakan yang terendah dengan persentase $0,6 \% .{ }^{12}$ Pada penelitian lainnya yang dilakukan di Puskesmas Tanah Kali Kedinding dan Rumah Sakit Mawadah Mojokerto tahun 2015 terdapat sedikit perbedaan dimana angka tertinggi terdapat pada kelompok Negative for Intraepithelial Lesion or Malignancy dengan persentase $86,4 \%$, namun terdapat kesamaan pada kelompok yang memiliki angka terendah yaitu pada kelompok High-grade squamous intraepithelial lesion (HSIL) dengan persentase $0 \%{ }^{7}$

\section{SIMPULAN}

Berdasarkan hasil penelitian karakteristik gambaran sitologi pap smear sebagai skrining terhadap pre kanker serviks pada tahun 2016 - 2017 yang telah memenuhi syarat inklusi, diperoleh simpulan bahwa pasien yang melakukan skrining pap smear di RSUP Sanglah Denpasar terbanyak terjadi pada kelompok 41-50 tahun yakni sebanyak jumlah paritas 0 (nullipara), tidak memiliki keluhan, dan karakteristik gambaran sitologi yang paling banyak ditemukan adalah Reactive cellular changes associated with Inflammation (RCCI).

\section{KONFLIK KEPENTINGAN}

Penulis menyatakan bahwa tidak terdapat konflik kepentingan dalam penulisan laporan hasil penelitian ini.

\section{ETIKA PENELITIAN}

Penelitian ini telah memperoleh persetujuan etik dari Komisi Etik Fakultas Kedokteran Universitas Udayana, Bali, Indonesia sebelum penelitian berjalan

\section{PENDANAAN}

Penulis bertanggung jawab mandiri terhadap pendanaan penelitian tanpa melibatkan pihak sponsor maupun beasiswa.

\section{KONTRIBUSI PENULIS}

Seluruh penulis memiliki kontribusi yang sama dalam penulisan artikel penelitian ini baik dari tahap pengumpulan data, analisis data penelitian, hingga laporan hasil penelitian.

\section{DAFTAR PUSTAKA}

1. Steben M, Duarte-Franco E. Human papillomavirus infection: epidemiology and pathophysiology. Gynecol Oncol. 2007;107(2 Suppl 1):S2-5.

2. Gillison ML, Castellsagué X, Chaturvedi A, Goodman MT, Snijders P, Tommasino M, et al. Eurogin Roadmap: comparative epidemiology of HPV infectionand associated cancers of the head and neck and cervix. Int J Cancer. 2014 Feb 1;134(3):497-507.

3. Wiebe E, Denny L, Thomas G. Cancer of the cervix uteri. Int J Gynaecol Obstet. 2012;119 Suppl 2:S100-9.

4. Prat J. Pathology of cancers of the female genital tract. Int J Gynaecol Obstet. 2015;131 Suppl 2:S132-45.

5. Rasjidi I. Epidemiologi Kanker Serviks. Indonesian Journal of Cancer. 2009;3(3):103-108.

6. Prabawa IPY, Bhargah A, Liwang F, Tandio DA, Tandio AL, Lestari AAW, et al. Pretreatment Neutrophilto-Lymphocyte ratio (NLR) and Platelet-to-Lymphocyte Ratio (PLR) as a Predictive Value of Hematological Markers in Cervical Cancer. Asian Pac J Cancer Prev. 2019;20(3):863-868. 
7. Mastutik G, Alia R, Rahniayu A, Kurniasari N, Rahaju AS, Mustokoweni S. Skrining Kanker Serviks dengan Pemeriksaan Pap Smeardi Puskesmas Tanah Kali Kedinding Surabaya dan Rumah Sakit Mawadah Mojokerto. Majalah Obstetri \& Ginekologi. 2015;23(2):54-60

8. Deas P, Ade W, Sofian A. Gambaran hasil pemeriksaan sitologi serviks wanita pekerja seksual tidak langsung pada Hotspot X Kecamatan Payung Sekaki Pekanbaru Putri. Jom FK. 2016;3(1):1-14

9. Rahmadani FT, Ade W, Sofian A. Gambaran Hasil Sitologi Serviks Wanita Pekerja Seksual Tidak Langsung Pada Hotspot X Kecamatan Marpoyan Damai Pekanbaru. Jom FK. 2016;3(2):1-12

10. Verma A, Verma S, Vashist S, Attri S, Singhal A. A study on cervical cancer screening in symptomatic women using Pap smear in a tertiary care hospital in rural area of Himachal Pradesh, India. Middle East Fertility Society Journal. 2017;22(1):39-42.
11. Mahadik JD, Patel S, Gupta S, Patel AS, Ramani PR. Epithelial abnormalities on Pap smear in Postmenopausal Women: A two-year hospital-based study. International Journal of Medical Science and Public Health. 2017;6(2):365-371.

12. Mehmetoglu HC, Sadikoglu G, Ozcakir A. Bilgel N. Pap smear screening in the primary health care setting: A study from Turkey. North American Journal of Medical Sciences. 2010;2(10):467-472.

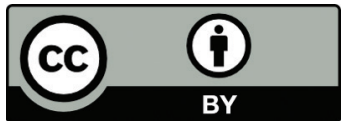

This work is licensed under a Creative Commons Attribution 